\title{
Workshop organisers: biographies
}

\section{Mel Collier}

Mel Collier is Professor at the Catholic University of Leuven and Director of the University Library. Mel has held Senior Library positions at Tilburg University in the Netherlands and at De Montfort University in the UK. His research and consultancy work is focused on digital libraries, learning development and change management.

Since the early seventies he has been active in research into the library applications of information technology. He has written and collaborated in numerous research reports, edited works and journal articles. He has served on several national and international bodies including the Library and Information Commission, the UK Government's advisory body for library and information matters. $\mathrm{He}$ was also chairman of the Library and Information Advisory Committee of the British Council. He has collaborated in and directed a number of projects within the EU frameworks since 1993, including TEL, ELISE, ELSA and MINSTREL.

\section{Biddy Fisher}

Biddy Fisher is Chair of the Library and Information Research Group of CILIP and works as Head of Information Services at Sheffield Hallam University. Biddy is a supporter of the evidence based approach of using research to inform and improve professional practice in Library and Information Services. Her own research activity began when she wrote a guide to mentoring for the LIS profession, and subsequently she has been active in the area of workforce development and skills and training. Biddy has participated in several projects on these issues and is currently on the project Steering Group for the MLA and LLUK Partnership Agreement focusing on the profile of the Libraries and Archives employment sector. Biddy has been a member of the Library Theory and Research Section of IFLA since 2005.

\section{Stephanie Kenna}

Since joining the British Library in 1975 Stephanie has worked in several areas including reader services, preservation and the former Research and Innovation Centre, where she was Research Analyst for the preservation research programme and the heritage sector. As a member of the Library's Co-operation and Partnership Programme from its establishment in 1999 until 2003, she had oversight for preservation issues and funding opportunities and was responsible for liaising with the archive and museum communities. She also developed and administered the Library's fund which supported co-operative projects in collaboration with the Research Support Libraries Programme and Resource (now the MLA Council).

\section{Stephanie currently manages the British} Library's regional programme, working closely with the public library sector to raise awareness of the Library's collections and services among both staff and users of public libraries. Since July 2006 she has been seconded half-time to the Library's Higher Education team as project manager for the "UK research reserve", a collaborative storage project. She was elected a Fellow of CILIP during 2006.

\section{Nigel Macartney}

Nigel Macartney is currently Director of Information Services at the University of Ulster, entailing responsibility for the library, archive, computing and reprographic services used by the 23,000 students and 3,500 staff of the University. He served as Director of the British Library Research and Innovation Centre between 1995 and 1999, where he encouraged the development of national research funding strategies and close co-operation between national library organisations. From 1982 to 1995 he was Librarian at the University of Hertfordshire, formerly Hatfield Polytechnic; 
Nigel's early career encompassed experience in public and further education libraries and he gained knowledge of European libraries through his work at the British Library and through an EU TEMPUS project involving collaborative work with Technical Universities in Poland. He has served on several government advisory committees. His current interests include learning resource centre design and implementation of IT and information strategies. $\mathrm{He}$ is also playing a leading role in the business process review programme being implemented at the University of Ulster. He is a member of the North Eastern Education and Library Board in Northern Ireland and Chairman of the Board's Library Committee. He is also Honorary Treasurer of the Chartered Institute of Library and Information Professionals. 